\title{
A construção da identidade discursiva em torno do consumo pela análise da personagem Solange de Fina Estampa ${ }^{1}$
}

\author{
The construction of identity discursive around the \\ consumption by analysis of Solange of Fina Estampa
}

\begin{abstract}
Eneus Trindade I eneustrindade@usp.br Possui graduação em Comunicação Social Publicidade e Propaganda pela Universidade Federal de Pernambuco (1995), mestrado em Ciências da Comunicação pela Universidade de São Paulo (1999), doutorado em Ciências da Comunicação pela Universidade de São Paulo (2003), Pósdoutorado em Antropologia Visual pela Universidade Aberta de Portugal (2009) e Livre-docência em Ciências da Comunicação pela USP (2012). Atualmente é professor regime de dedicação integral à docência e à pesquisa - 40 horas da Universidade de São Paulo(USP), na Escola de Comunicações e Artes (ECA). Na Graduação o docente é responsável pela matéria de Teoria e Técnica da Publicidade do Curso de Publicidade e Propaganda. No Programa de Pós-Graduação em Ciências da Comunicação(PPGCOM), o docente atua desde 2007, orientando no mestrado e no doutorado.O professor tem experiência na área de Comunicação, com ênfase em Linguagem Publicitária, atuando principalmente nos seguintes temas: estética e consumo, produção de sentido em publicidade e propaganda, estudos da enunciação e da recepção em linguagens

publicitárias e práticas de consumo. É Líder biêncio (2012-2013) do Grupo de Estudos em Semiótica Comunicação, Cultura e Consumo (GESC3) e membro do Grupo de Pesquisa Coletivo de Estudos em Estética, ambos cadastrados no CNPq.

Rosana Mauro I mauro.rosana@gmail.com Possui graduação em Jornalismo pela Universidade Metodista de São Paulo (2005). Especializada em Comunicação Organizacional - Relações Públicas pela Faculdade Cásper Líbero (2007). Tem experiência na área de Comunicação Empresarial e Publicidade. Está cursando mestrado na ECA/ USP, em Ciências da Comunicação na linha de pesquisa Consumo e Usos Midiáticos nas Práticas Sociais. Participa do GESC3 Grupo de Estudos em Semiótica, Comunicação, Cultura e Consumo.
\end{abstract}

Palavras-chave: As telenovelas brasileiras, principalmente as transmitidas pela Rede Globo, maior emissora do país, representam um produto de grande importância na sociedade de consumo nacional. O presente artigo pretende explorar esse universo por meio da análise de Solange, da telenovela da Rede Globo Fina Estampa, de Aguinaldo Silva. O objetivo é averiguar como o discurso da personagem se relaciona com o consumo.

Parole chiave: Telenovela, consumo, discurso.

Abstract: The Brazilian soap operas, especially those transmitted by Rede Globo, the largest broadcaster of the country, represent a product of great importance in the national consumer society. This article seeks to explore this universe through the analysis of Solange of Fina Estampa, soap opera wrote by Aguinaldo Silva. The goal is to ascertain how the character's discourse relates to the consumption.

Keywords: Soap opera, consumption, discourse. 
O apelo mercadológico das telenovelas brasileiras não representa nenhuma novidade, pois já é sabido que elas fazem parte do sistema publicitário de nossa cultura e têm grande representatividade no cotidiano brasileiro. Segundo Almeida (2003, p. 163), a telenovela pode ser uma vitrine náo só de produtos, mas também de estilos de vida associados aos bens de consumo. As tramas mostram como as personagens se vestem, se comportam e consomem bens e serviços. Ademais, Almeida (2003, p.169) atenta para o fato de que as telenovelas funcionam de modo semelhante aos anúncios, com a vantagem de terem mais tempo e espaço para trabalhar o universo do consumo. Além de demonstrar didaticamente o uso de certos bens, elas permitem uma identificação entre o produto e seu usuário ideal (ALMEIDA, 2003, p.192).

A autora expõe em seu estudo a inspiração que a telenovela $O$ Rei do Gado despertava em determinadas telespectadoras entrevistadas. Uma delas, inclusive, comenta o fato de assistir à trama para apreciar a decoração e os móveis das "casas" mostradas e, assim, ter ideias sobre como mudar a própria residência (2003, p.173). Além de decoração, maquiagens, roupas e outros produtos tornam-se referências para o público, independente da exposição direta de marcas, como ocorre com o merchandising. Afinal, as telenovelas podem incitar o desejo de consumir de modo direto, por meio da exposição explícita de marcas, e também através dos discursos das personagens, de seus comportamentos e toda a gama de produtos e utensílios expostos nos cenários.

Cabe-nos aqui averiguar como os discursos e as identidades discursivas de determinadas personagens possibilitam um diálogo suscetível de significaçôes ligadas ao consumo. $\mathrm{O}$ presente artigo faz parte de um projeto maior, portanto não há a expectativa de esgotar o assunto, muito menos de mergulhar profundamente no universo de tais ficçóes e analisar as personagens detalhadamente. Por ora, foi escolhida uma personagem da telenovela Fina Estampa, de Aguinaldo Silva, transmitida na Rede Globo em 2011 e começo de 2012. Trata-se de Solange.

Para tal análise, utilizaremos os conceitos de ethos e pathos. De acordo com Maingueneau (2004, p. 95-96), o ethos refere-se ao orador, contemplando uma postura que extrapola o texto em si e situa em seu meio circundante a imagem que este orador quer construir sobre si mesmo frente a um auditório, desencadeando possíveis reaçóes. Para o autor, o ethos é como um fiador do que é dito, uma espécie de voz que não está explícita no enunciado e por isso mesmo é eficaz. O ethos pode ser construído pelo público a partir de um conjunto de indícios.

Ao fiador, cuja figura o leitor deve construir a partir de indícios textuais de diversas
ordens, sáo atribuídos um caráter e uma corporalidade, cujo grau de precisáo varia
segundo os textos. O "caráter" corresponde a uma gama de traços psicológicos. Já a
"corporalidade" corresponde a uma compleiçáo corporal, mas também a uma maneira
de se vestir e de se movimentar no espaço social. (MAINGUENEAU, 2004, p. 98-99).

Dessa forma, o ethos pode ser considerado em todo o contexto sociocultural e contemporâneo brasileiro das telenovelas e suas personagens femininas, como uma maneira de corporificar imagens de seus enunciadores, autores, personagens. Essas imagens, essas vozes enunciativas dos discursos das personagens 
estão em seus estilos de falar, de se vestir e se relacionar, por exemplo. O pathos, por sua vez, se refere à plateia, à reação do público, que pode ser positiva ou negativa. Trata-se justamente do despertar da emoção capaz de gerar identificação, da empatia ou antipatia que os telespectadores podem desenvolver em relaçáo à telenovela e suas personagens. É importante salientar que este trabalho pretende abordar o ethos de maneira plural, em conjunção com a identidade do homem pós-moderno (HALL, 2011, p.12) que não se configura em uma identidade única e fechada e, sim, em múltiplas identificações.

Antes de entrar no mundo da personagem Solange, é pertinente situar a telenovela como uma obra social, no sentido em que Bakhtin (2002, p.119) classifica toda enunciação e discurso. De acordo com o autor, não existe discurso individual que não seja impregnado pelo seu meio social, pois ele se dá dialogicamente, em sintonia com o outro e a sociedade, e, assim, é ideológico por princípio (BAKHTIN, 2002, p. 117). Além disso, o discurso tem sempre um caráter responsivo, ele surge em resposta a outro discurso proferido em um dado momento. Uma enunciação nunca é original e primeira, ela está continuamente em relação ao que já foi dito em algum lugar, em alguma época. Diante de tais concepçóes, podemos considerar a telenovela e, consequentemente, as identidades discursivas de suas personagens, como os produtos de seu meio social, impregnados pelas marcas da sociedade contemporânea brasileira, por seu momento social, econômico e político: "Cada época e cada grupo social têm seu repertório e formas de discurso na comunicação sócio-ideológica” (BAKHTIN, 2002, p.43). Outros autores retomam ideias semelhantes à de Bakhtin tempos depois para a construção de metodologias como a Análise de Discurso, da qual abordaremos alguns elementos no decorrer do artigo.

A telenovela também deve ser considerada como um produto cujo discurso é híbrido por natureza. Ela apresenta uma mistura de sons, imagens, conversas com outras plataformas midiáticas (no caso da transmidiatização) e a utilização de uma linguagem heterogênea, que constitui um misto de gêneros, que une o publicitário, romanesco, cômico, cinematográfico, literário, entre outros. $\mathrm{O}$ discurso midiático (BARBOSA; TRINDADE, 2007, p. 59 -60), de uma forma geral, é heterogêneo e sincrético e requer uma análise que considere mais que o discurso linguisticamente, mas, sim, o situe em dialogia com outras instâncias.

Se a enunciação depende da interação entre sujeitos em contextos espaço-temporais precisos, os discursos também se materializam e se plasmam com marcas: actanciais (sujeitos); topológicas (espaço); histórico-culturais (tempo), que viabilizam as práticas discursivas. Esses traços constitutivos dos processos enunciativos são denominados deiticos [...] (BARBOSA;TRINDADE, 2007, p. 61).

Considerando tais premissas, podemos refletir sobre o contexto social brasileiro, no qual a telenovela Fina Estampa esteve inserida durante a sua exibição. Dois fatores chamam a atenção para a construção dos ethê de Solange: a representação da classe $\mathrm{C}$ emergente e a transmidiatização. 
Nos últimos anos, o Brasil está presenciando a ascensão de uma nova classe C, que já inclui 110 milhôes de pessoas e representa $50 \%$ do poder do consumo nacional ${ }^{3}$. Essa ascensão tem influenciado significativamente o mundo da ficção televisiva brasileira (LOPES; GÓMEZ, 2011, p.135). A Rede Globo vem se esforçando no sentido de dialogar com esse novo público, incluindo em sua programação atraçóes voltadas para a nova classe $\mathrm{C}$, além de inserir personagens em suas telenovelas que representam esse perfil de telespectador, o que contraria de certa forma a tradição das telenovelas em expor personagens abastadas para incitar o desejo por um mundo luxuoso, com mansóes perfeitamente decoradas, habitadas por madames sofisticadas, perfeitamente vestidas com roupas de grife, consumindo produtos caros totalmente fora da realidade brasileira. É perceptível um movimento que visa valorizar a nova classe $C$, seu jeito de ser, seu universo de consumo e seu gosto cultural (de maneira romanceada, por essência das ficçóes melodramáticas). É o caso da adolescente Solange, que vive em uma comunidade no subúrbio do Rio de Janeiro, junto de sua mãe Celeste, mulher submissa a Baltazar, o pai da família que trabalha de motorista na casa de uma das protagonistas, Tereza Cristina, e agride sua mulher.

A forma de falar e a vestimenta de Solange revelam os hábitos e gostos de uma classe emergente. A jovem, em idade escolar, tem forte relaçáo com o funk, estilo musical vindo do morro do Rio de Janeiro. Ela sonha em ser uma funkeira famosa, dança e compóe suas próprias músicas. A garota usa roupas curtas e apertadas (como miniblusas, saiais com tiras transparentes nas laterais, ela, inclusive, amarra na frente a blusa do uniforme escolar para deixar a barriga à mostra), esmalte com cores chamativas (a coloração amarela, por exemplo, foi muito usada pela personagem) que caracterizam todo um estilo em convergência com as funkeiras da periferia. Nota-se também nessa caracterização um ponto forte relacionado às classes emergentes, a reprodução do estereótipo do esporte e da música (no caso, o funk) como únicas maneiras de ascensão social das classes emergentes, no lugar dos estudos e da formação universitária. A própria letra de uma das músicas de Solange alude à questão: "reprovada no provão, tirei 10 no popozão".

É pertinente atentar que mesmo com os desfechos positivos da narrativa em torno de Solange, seu próprio sucesso como funkeira e o fato de sua mãe ter aberto um restaurante (em sociedade com a protagonista Griselda) que deslancha logo em seus primeiros dias de vida, não há uma transformação narrativa das personagens para uma classe superior ou uma mudança visível no padrão de consumo. Uma hipótese a ser considerada é o interesse da emissora e do autor da trama em manter a personagem ligada e identificada com a classe social emergente, novo público consumidor e foco da Rede Globo.

Juntamente com o ethos social descrito acima, é possível averiguar outras identidades discursivas de Solange. De acordo com Maingueneau (1989, p.112), um único discurso pode englobar mais de uma visão discursiva, por meio de um diálogo entre diferentes enunciados. O autor (MAINGUENEAU, 1989, p. 
116) classifica três instâncias discursivas nas quais esse diálogo ocorre: o universo discursivo (abrangente, com inúmeras possibilidades), o campo discursivo (mais delimitado) e o espaço discursivo (que liga pelo menos duas formaçôes discursivas mais importantes). Desse modo, por mais que um discurso de uma dada personagem pareça homogêneo, ele está impregnado de repertórios, pois a sua formação se dá através da interdiscursividade, sendo assim, aberta e instável.

De fato, uma formação discursiva não deve ser concebida como um bloco compacto que se oporia a outros (o discurso comunista contra o discurso democratacristão, por exemplo), mas como uma realidade heterogênea por si mesma. (MAINGUENEAU, 1989, p. 112).

Assim, podemos identificar em Solange outros ethé, como o da libertação feminina, em oposição à masculinidade e autoridade expressas por seu pai Baltazar. Para abordar este aspecto, é imprescindível falar também de sua mãe Celeste, que reproduz um problema social do país, a agressão doméstica de maridos contra esposas. No decorrer da trama, Celeste consegue se impor de forma parcial, ela coloca o marido para fora de casa por duas vezes, mas o aceita de volta na condição de dormirem separadamente. Solange sofre as consequências desse problema, da mesma forma que Baltazar reprime sua mãe, e esta não se impóe adequadamente, a menina também é submetida à imposição masculina. $\mathrm{O}$ homem não aceita que ambas se maquiem e se arrumem demais, mas elas resistem e "desobedecem" a tais ordens.

Desse modo, a vaidade feminina desempenha uma espécie de força que as empurra para fora dessa opressão. A maquiagem, especificamente, é uma metáfora para essa liberaçáo feminina e constitui um produto com grande apelo para o consumo entre as mulheres jovens que se identificam com esse perfil e desejam, como Solange, livrar-se da opressão paterna. Da mesma forma, o rádio e a música de Solange representam a alegria, a descontração e a liberação proibidas por Baltazar, que, por muitas vezes, proibiu que a menina ouvisse música e dançasse dentro de casa. Em um dado momento, Celeste compra escondido do marido um rádio para a filha ensaiar, e toda vez que o homem está prestes a chegar do serviço, ambas correm para esconder o objeto.

Se formos mais longe, podemos relacionar ainda a vaidade feminina de Solange com a nova identidade discutida por Stuart Hall (2011), desenvolvida com a pós-modernidade ou modernidade tardia, se usarmos as palavras do autor. Essa identidade é fragmentada, não é única e compacta como a concebida pelo homem cartesiano do século XVIII (HALL, 2011, p. 26-27). Se antes o homem era tido como um ser racional, lógico e masculino, hoje, a identidade é fragmentada, múltipla, aberta e feminina no sentido de sua flexibilidade. $\mathrm{O}$ ethos da liberação feminina de Solange seria, assim, a flexibilidade e a fragmentação do ser na era pós-moderna, enquanto Baltazar é símbolo do antiquado, ultrapassado, estereótipo do masculino autoritário e austero.

Outra questão que nos remete às novas identidades da pós-modernidade é a quase ausência do poder da polícia no caso da agressão contra Celeste 
e da escola na educação de Solange. Celeste recorre à polícia, mas esta não desempenha papel importante na narrativa, o foco está nas próprias atitudes de Celeste. Do mesmo modo, Solange aparece com o uniforme da escola, mas sempre fora desta, nunca em situação de estudo. Tais observações corroboram com a visão pós-moderna da perda de poder das instituiçôes oficiais e a força presente na vontade do indivíduo.

Encontramos, ainda, um discurso contraditório ao ethos da liberação feminina. Trata-se do repertório tradicional e conservador, revelado na valorização da virgindade de Solange e do casamento com o final feliz da personagem. Na gravação de seu clipe, Solange afirma ser virgem, discurso que contraria toda a cultura funk de liberação sexual. Apesar de sua carreira estar despontando, Baltazar continua a ser seu empresário, responsável por marcar suas entrevistas em programas de televisão e a cuidar de suas finanças, ao invés de sua mãe Celeste, revelando submissão ao poder patriarcal. A relação de Solange com Daniel, com o qual a personagem perde sua virgindade, revela valores antigos arraigados em uma cultura patriarcal, com a mulher à espera do parceiro ideal (apesar da menina sempre ter tomado a iniciativa para que o relacionamento tivesse início, chegando até mesmo a entrar no carro do rapaz sem sua permissão e a roubar-lhe beijos). Assim como nos contos de fadas, Daniel é de uma classe social superior, é estudante de medicina, carinhoso e bondoso, um verdadeiro príncipe encantado pós-moderno. Encontramos aí um retorno à tradição, à idealização da mulher virgem e do amor perfeito que se opóe à imagem da jovem funkeira.

Essas contradiçóes podem ser explicadas ao considerarmos a cultura e os valores do público da telenovela, pois o enunciatário é pressuposto pelo enunciador na elaboraçáo de sua mensagem, para que esta seja adequada ao gosto e valores de seu público-alvo, como está ocorrendo com a ascensão da nova classe C.

Apesar desses novos movimentos, o público padrão da telenovela é mais tradicional, em sua maioria acima de 50 anos $^{4}$, e muito provavelmente cultua valores e costumes ligados à família e à moral. Inclusive, se analisarmos o visual funk na vida real, as roupas de Solange podem ser consideradas comportadas. Em uma reportagem publicada na internet ${ }^{5}$, algumas funkeiras foram chamadas para abordar a personagem Solange e muitas argumentaram que ela poderia abusar mais do salto alto e das peças curtas, e dáo a entender que o estilo de Solange é de uma garota bem jovem, de alguém que está apenas começando.

O mesmo dado serve para explicar por que Solange não vivencia nenhuma cena de merchandising ${ }^{6}$, enquanto sua mãe Celeste faz propaganda da Maxton. É possível deduzir que com o anúncio pretende-se atingir o perfil geral do público, a maioria constituída por mulheres mais velhas. Nessa cena de merchandising, Crodoaldo Valério, o "Crô", vizinho de Celeste, propóe a ela arrumá-la, maquiando-a e pintando seu cabelo com a coloração Maxton, da Embelleze. Celeste resiste, pois acha que Baltazar não iria gostar de tanta produçáo. "Crô" insiste e no fim ela cede (ethos da liberação feminina) e se satisfaz com o resultado. 
Embora Solange não tenha passado por nenhuma cena de publicidade explícita no período analisado, houve um movimento de telespectadoras em blogs na internet comentando os produtos usados pela personagem. Tal fato ocorreu com as sandálias da marca Melissa, que foram identificadas nos pés da personagem e rendeu postagem em um blog comandado por fấs do calçado.

O exemplo citado acima nos remete a outra questão que o presente artigo pretende abordar, a transmidiatização, que significa a comunicação entre diferentes plataformas midiáticas (JENKINS, 2009) - no caso, entre a telenovela e as mídias digitais, como uma forma de cultivar o interesse pela narrativa (tanto por iniciativa da produção quanto dos receptores). A transmidiatização é abordada dentro da própria trama em torno de Solange, diante da qual podemos identificar na personagem outro ethos bastante compatível com o da liberação feminina, que é o da juventude, da contemporaneidade e das novas tecnologias. A Rede Globo tem se esforçado para inserir em suas telenovelas situaçôes que dialoguem com as novas tecnologias.

Isso se dá pela situação que estamos vivenciando no mundo todo, da cultura da convergência (JENKINS, 2009), na qual os receptores estão mais ativos e sofrem a influência das mídias digitais que propóem uma comunicação horizontal e participativa. Muitos produtos culturais já são pensados, inclusive, para serem distribuídos em diversas mídias, para que o público possa interagir de variadas formas, participando da construçáo da narrativa ou em comunidades de fẫs. Porém, esse movimento não depende de uma ação do produtor, há também a atitude espontânea dos telespectadores que migram para a internet em busca de interação, para trocar informaçóes, expressar ideias sobre os produtos culturais, etc.

De acordo com Lacalle (2010, p.95), temos agora a figura do telenauta, um receptor juiz e parte dos programas que prefere. Estamos no meio de um processo de comunicação mais complexo e circular, e não retilíneo como já foi concebido. O telenauta se manifesta na internet, participa de grupos e comunidades sobre seus produtos televisuais preferidos e tem um papel, em alguns casos, influenciador nas produçôes culturais. É oportuno observar também que, de maneira diversa do imaginado por muitos teóricos, estudos experimentais revelam o reforço do papel da televisão com a internet. No meio cibernético, muito comumente, os assuntos de maior destaque se referem aos produtos televisuais, além de muitos produtos audiovisuais transmitidos na internet ainda seguirem o modelo estabelecido pela televisão.

Nesse contexto, podemos averiguar a comunicação transmidiática com alguns personagens de Fina Estampa, como Solange, que lança o seu videoclipe na internet, prática comum entre jovens que procuram visibilidade em busca de sucesso. $\mathrm{Na}$ verdade, Solange não domina as ferramentas digitais, talvez pelo seu ethos social mais modesto, mas está aberta a essas tecnologias. A ideia surge de "Crô" que enxerga na divulgação pela internet uma oportunidade para a garota obter o sucesso. Logicamente, Baltazar, que representa a força retrógrada e 
autoritária desse núcleo, vai contra a postagem na internet. Quem faz a gravação da moça e divulga o produto final na web é Daniel que está inserido no núcleo jovem mais abastado da trama. Curiosamente, o rapaz conta com a ajuda de Vilma (interpretada por Arlete Salles), uma personagem mais velha que trabalha como taxista e desempenha o papel de jornalista, publicando reportagens em seu blog, chamado Modem Express. Vemos aí uma representação da inserção do público mais velho no meio digital.

Daniel grava o clipe de Solange aos poucos, com cenas da funkeira dançando na rua e no baile funk. Daniel grava também o momento em que o pai de Solange invade o palco com revolta, o que acaba se tornando motivo de comédia posteriormente para outros personagens, que acessam o vídeo com o objetivo de dar risada, o que acontece muito frequentemente na vida real. Outro ponto de dialogia com a realidade e com o perfil do público em potencial da personagem está em uma cena, na qual Solange e Daniel conversam dentro do carro, ela diz que deseja que o seu vídeo seja parecido com o de Stefhany, a absoluta. Solange se refere a uma garota do mundo real que ficou famosa ao postar os vídeos gravados por ela mesma cantando, em formato de um clipe, no You Tube. Tal prática é cada vez mais comum na cultura da internet, na qual qualquer pessoa pode ficar instantaneamente famosa. Foi exatamente isso o que aconteceu com Solange na telenovela.

$\mathrm{Na}$ trama, a postagem do videoclipe rendeu a Solange repercussão positiva, com convites para entrevistas na mídia e sessão de fotos. $\mathrm{Na}$ vida real (virtual) é possível visualizar mais de uma postagem do mesmo videoclipe ${ }^{7}$ no You Tube, um deles conta com mais de 90 comentários, 32 pessoas adicionaram o produto nos favoritos e 391 internautas afirmaram gostar do videoclipe. Além disso, há mais "vídeos" postados apenas com áudio de outras cançôes da personagem (de sucessos que não foram lançados "oficialmente" em videoclipe pela telenovela) e exibiçóes de imagens da personagem com sua música tema na trama, "Danada Vem Que Vem”. Tudo isso comprova a iniciativa e o interesse do próprio público em compartilhar vídeos de Solange. Ainda é possível comprovar a popularidade da funkeira por meio de seu perfil no site de relacionamento Orkut, que conta com 1065 seguidores, em sua maioria meninas aparentando ter idade próxima à de Solange.

Apesar dessas experiências com Fina Estampa e outras obras (como Passione e $T i T i T i$, por exemplo), a telenovela possui alguns entraves que atrapalham uma maior exploração da comunicação transmidiática (LOPES, 2011, p. 41). Diferente das séries americanas, que têm grande participação do público na busca de mais informaçôes, na construção de comunidades duradouras e coesas em torno das tramas, as telenovelas possuem um público menos habituado com as mídias digitais. Em adição a tal fato, o próprio formato dessas produçóes televisuais - com começo meio e fim bem delimitados - dificulta a perpetuação da comunicação nas mídias digitais em cima de uma mesma telenovela e/ou personagem por um tempo maior além do qual a trama é transmitida. Ao contrário do que ocorre com as séries americanas, que são transmitidas por diversas temporadas. 


\begin{abstract}
A telenovela está sujeita ao que alguns produtores chamam de "morte súbita". $O$ espectador é estimulado a "entrar" em um determinado mundo ficcional e a acompanhar intensamente um conjunto de personagens por um bom periodo de tempo, mas esse convivio tem "prazo de validade", data marcada para acabar. O último capitulo da telenovela implica também no completo "desaparecimento" na TV e na estagnação em outras plataformas (Internet, Twitter etc.) daquele universo ficcional com o qual o espectador foi convidado a se familiarizar e a se envolver durante meses. (LOPES, 2011, p. 43)
\end{abstract}

Mesmo diante de tais limes, é preciso levar em consideração que cada vez mais a telenovela se torna uma obra em construçáo, que conta com a participação da opinião pública para a sua conclusão, na qual a resposta do público (pathos) assume grande importância. O próprio escritor de Fina Estampa, Aguinaldo Silva, possui um blog e um perfil no Twitter para interagir com os "telenautas". Ele é acompanhado por outros escritores de telenovela, produtores, diretores e atores que se lançam na web para compartilhar ideias com o público. Dessa forma, a transmidiatizaçáo tem se mostrado um espaço rico para a expansão, de forma lúdica, do universo de consumo proposto pela telenovela.

\title{
Considerações Finais
}

$\mathrm{O}$ presente artigo identificou quatro ethé da personagem Solange de Fina Estampa. O ethos social da classe C emergente; o ethos da liberação feminina; o ethos da tradição patriarcal e o ethos da juventude e das novas tecnologias. O ethos social está presente em todas as outras identificaçóes, como uma espécie de guarda-chuva que cobre o mundo de Solange o tempo todo. O ethos da liberação feminina e o das novas tecnologias conversam entre si e se opóem à identidade da tradição e da moral. Apresentam-se, assim, no espaço discursivo dois discursos concorrentes: o da tradição e o da liberação, que pretendem conversar com dois públicos diferentes, o conservador e o jovem, composto pelas garotas da classe emergente e apreciadoras de funk, parte de uma nova potência consumidora no país.

Tais identificações revelam o caráter heterogêneo dos discursos, suas várias possibilidades interdiscursivas, dentro de um único discurso que se mostra como homogêneo. A identidade social da classe emergente, aparentemente homogênea, expóe o grande interesse da Rede Globo em alcançar essa nova classe social em ascensão no país. $\mathrm{O}$ funk como um gênero de grande representação entre a juventude e a classe emergente (não só na classe emergente, visto tratar-se de um gênero musical que veio do morro e espalhou-se para as classes superiores) é capaz de gerar grande identificação e apelo de consumo entre as jovens, pois ele é constituído por uma série de acessórios, como roupas, maquiagem, sapato, esmalte, entre outros.

Ao mesmo tempo, a cultura funk de liberação feminina e jovem é incompatível com o público conservador das telenovelas. Sendo assim, a trama recorreu a costumes tradicionais como forma de "moralizar" o discurso por meio da 
presença de Baltazar, que recrimina muitas atitudes da filha, e com a valorização da virgindade e do casamento, utilizando o personagem Daniel como pivô.

Desse modo, Solange representa uma personagem rica em significaçóes de consumo de produtos e comportamentos, condizentes com as jovens da classe $\mathrm{C}$ emergente. Ainda assim, ela não desagrada o público tradicional e conservador da telenovela, "vendendo" de certa forma a idealização da garota virgem que se casa com um bom rapaz. É como se o retorno à tradição conferisse autoridade ao ethos fiador (MAINGUENEAU, 2004) capaz de atribuir autoridade ao discurso diante de um público e legitimá-lo como aceitável. Por outro lado, o seu diálogo com as mídias digitais cria um universo lúdico de retroalimentação com a trama, apesar de tratar-se de um terreno novo ainda em experimentação pelas telenovelas.

Podemos concluir também que Solange e a telenovela de modo geral são construídas em dialogia com a situação social do país e do mundo, em concordância com elementos da contemporaneidade, do homem pós-moderno, fragmentado e múltiplo, que vivencia a compressão do espaço e tempo, tendo o consumo como força motriz. É justamente através desse diálogo entre ficção e realidade que a telenovela é capaz de atuar na construção de novas realidades e desejos de consumo.

\section{Referências Bibliográficas}

ALMEIDA, Heloisa B. de. Telenovela, Consumo e Gênero. Bauru, SP: EDUSP, 2003.

BAKHTIN, Mikhail (V. N. Volochínov). Marxismo e Filosofia da Linguagem. São Paulo: Hucitec Annablume, 2002.

BARBOSA, Ivan Santo; TRINDADE, Eneus. Enunciação Publicitária e suas possibilidades. Acta Semiotica et Linguistica, v. 12, p. 59-70, 2007.

JENKINS, Henry. Cultura da Convergência. Tradução: Susana Alexandria. São Paulo: Aleph, 2009.

HALL, Stuart. A Identidade Cultural na Pós-Modernidade. Tradução: Thomas Tadeu da Silva e Guacira Lopes Louro. Rio de Janeiro: DP\&A, 2011.

LACALLE, Charo. As novas narrativas da ficção televisiva e a Internet. Revista Matrizes. São Paulo. v.3, n.2, p.79-102, 2010.

LOPES, Maria Immacolata Vassallo de (org.). Ficçâa Televisiva transmidiática no Brasil: plataformas, convergência, comunidades virtuais. Porto Alegre: Sulina, 2011.

LOPES, Maria Immacolata Vassallo de. \& GÓMEZ, Guilherme Orozco (orgs.). Qualidade na fiç̧ão televisiva e participação transmídia das audiências. Tradução: Pablo Cardellino Soto e Maria Paula Gurgel Ribeiro. Rio de Janeiro: Editora Globo, 2011. 
MaingueneaU, Dominique. Análise de Textos de Comunicação. Tradução: Cecília P. de Souza e Décio Rocha. São Paulo: Cortez, 2004.

MAINGUENEAU, Dominique. Novas Tendências em Análise do Discurso. Tradução: Freda Indursky. Campinas: Pontes/UNICAMP, 1989.

\section{Notas}

1. Trabalho adaptado do texto originalmente publicado no III Pró-Pesq PP - Encontro de Pesquisadores em Publicidade e Propaganda, CRP/ECA/USP.

2. Plural de ethos.

3. Informaçóes retiradas de reportagem da Veja online. Disponível em: <http://veja. abril.com.br/noticia/celebridades/globo-reforca-investida-em-classe-c-em-2012> Acesso em 01 abril 2012.

4. Dados do Observatório Ibero-Americano de Ficção Televisiva (OBITEL) sobre a audiência dos dez títulos de teledramaturgia brasileira mais vistos em 2009 (LOPES, 2011).

5. Disponível em: <http://www.divirta-se.uai.com.br/html/sessao_9/2012/01/09/ ficha_mexerico/id_sessao=98id_noticia $=48265 /$ ficha_mexerico.shtml $>$.

6. Os episódios analisados foram exibidos em janeiro, fevereiro e março de 2012.

7. O videoclipe foi postado originalmente no blog da personagem Vilma. Disponível em: <http://tvg.globo.com/platb/finaestampa-modem-express/>. Não é possível saber se a postagem no You Tube foi feita pela própria telenovela ou se os telespectadores que a compartilharam. 